\title{
Association of GHR $\mid$ AluI gene polymorphism with body weight parameters in Grati-PO cattle
}

\author{
H. Hartati ${ }^{1 *}$, A.A.R. Hapsari ${ }^{2}$, B.D.P. Soewandi ${ }^{2}$, S. Anwar ${ }^{3}$, S. P. Rahmadani ${ }^{4}$, A. Aryogi ${ }^{1}$ \\ and D. Pamungkas ${ }^{1}$ \\ ${ }^{1}$ Indonesian Beef Cattle Research Station, Indonesian Agency for Agricultural Research and \\ Development, Ministry of Agriculture of Indonesia, Jl. Pahlawan No. 2 Grati, Pasuruan, \\ East Java 67184 - Indonesia \\ ${ }^{2}$ Indonesian Research Institute for Animal Production (IRIAP), Ciawi, Bogor-Indonesia \\ ${ }^{3}$ Research Center for Biotechnology, National Research and Innovation Agency (BRIN), \\ Jl. Raya Bogor Km. 46, Cibinong 16911, West Java Indonesia \\ ${ }^{4}$ Graduate Student of Animal Husbandry, University of Jambi \\ *Corresponding Email: hartatifakhri16@gmail.com
}

Received February 13, 2021; Accepted August 6, 2021

\begin{abstract}
ABSTRAK
Gen growth hormone receptor (GHR) merupakan anggota dari famili reseptor sitokin kelas I yang penting dalam regulasi pertumbuhan termasuk pada sapi. Penelitian ini bertujuan untuk menganalisa asosiasi antara gen GHR $\mid A l u \mathrm{I}$ dan parameter bobot badan pada populasi sapi PO Grati. Sebanyak 304 sampel darah sapi PO dikoleksi dari kandang percobaan Loka Penelitian Sapi Potong yang dilengkapi dengan 304 data fenotipiknya. Sampel darah diisolasi menggunakan zymo extraction kit. Deteksi keragaman gen GHR menggunakan metode polymerase chain reaction-restriction fragment length polymorphism (PCR-RFLP) dengan enzim pemotong AluI. Indikator polimorfisme meliputi frekuensi genotipe, frekuensi alel, Hardy-Weinberg Equilibrium, heterozigositas pengamatan (Ho), heterozigositas harapan (He), polymorphism information content (PIC) dan jumlah alel efektif $(\mathrm{Ne})$. Analisis asosiasi dilakukan menggunakan linier mixed model. Performans bobot lahir, bobot sapih, bobot setahun dan bobot umur 18 bulan masing-masing adalah $25,4 \pm 0,2 \mathrm{~kg} ; 113,8 \pm 2,3$ $\mathrm{kg} ; 159,9 \pm 2,7 \mathrm{~kg}$; dan 213,7 $\pm 3,6 \mathrm{~kg}$. Hasil analisis asosiasi signifikan $(\mathrm{p}<0,05)$ pada bobot sapih, bobot setahun dan bobot umur 18 bulan. Gen GHR berpotensi sebagai penanda genetik untuk sifat pertumbuhan dan dapat digunakan sebagai kandidat penanda genetik untuk seleksi sapi PO-Grati.
\end{abstract}

Kata kunci: Bobot badan, Growth hormone receptor, Polimorfisme, Sapi PO-Grati

\begin{abstract}
The growth hormone receptor (GHR) gene is member of the class I cytokine receptor family that important in growth regulation including in cattle. This study aimed to analyze the association between GHR $\mid A l u$ I gene with body weight, parameters in Grati-PO cattle population. A total of 304 blood samples were collected from the experimental station at the Beef Cattle Research Station, which
\end{abstract}


were also equipped with 304 phenotypic data. DNA was extracted using a zymo extraction kit. Detection of of the polymorphism of GHR gene using PCR-RFLP method with AluI restriction enzymes. polymorphism indicators include genotype frequency, allele frequency, Hardy-Weinberg Equilibrium, observed heterozygosity (Ho), expected heterozygosity (He), polymorphism information content (PIC) and number of effective alleles $(\mathrm{Ne})$. Association analysis was carried out using a linear mixed model. The performance of birth weight, weaning weight, yearling weight and 18 months weight were $25.4 \pm$ $0.2 \mathrm{~kg} ; 113.8 \pm 2.3 \mathrm{~kg} ; 159.9 \pm 2.7 \mathrm{~kg}$ and $213.7 \pm 3.6 \mathrm{~kg}$, respectively. The result of association analysis was significant $(\mathrm{P}<0.05)$ on weaning weight, yearling weight and 18 months weight. It could be concluded that the GHR gene has potential to be a candidate genetic marker for growth traits in GratiPO cattle.

Keywords: Body weight, Growth hormone receptor, Polymorphism, PO-Grati cattle

\section{INTRODUCTION}

Growth traits is one of the most important economic traits in beef cattle production. Body weight, body size measurements and weight gains are several types of growth traits. Growth traits have relationship between growth traits itself or with carcass and meat component (Meyer, 1995; Albertí et al., 2008; Caetano et al., 2013; Coyne et al., 2019), so it is widely used as a selection criterion in beef cattle breeding program. Body weight measurement is the most common type of growth traits used in the selection program, which are taken from birth and throughout an animal's life (Buzanskas et al., 2014).

The growth trait was controlled by many genes and their expression was the accumulation effects of genetic, environmental and interaction (Putra et al., 2014). Several genes that were thought to be the main genes in influencing growth traits were growth hormone $(\mathrm{GH})$ and growth receptor (GHR) genes. The mechanism of action of these two genes has interrelated activities in influencing cell growth and metabolism in vertebrates. The $\mathrm{GH}$ gene in influencing growth and metabolism will interact with a specific receptor called the growth hormone receptor (GHR) on the surface of the targeted cell (Di Stasio et al., 2005).

Growth hormone $(\mathrm{GH})$ has proven to be the major regulator of postnatal growth and metabolism in mammals and thus affects growth rate, body composition, health, milk production, and aging by modulating the expression of many genes (Ge et al., 2003). The growth hormone receptor (GHR) is a member of the class I cytokine receptor family with a single transmembrane domain (Waters and Brooks, 2015; Chia, 2014). GH receptor (GHR) are active in the central nervous system (CNS) and are crucial in regulating several aspects of metabolism (Cady et al., 2017). Therefore, the essential biological function of GHR, makes the GHR gene proposed as a potential candidate gene for several economically desirable traits including growth traits. The bovine GHR gene has been assigned located on bovine chromosome 20 (Moody et al., 1995).

The polymorphism of the bovine GHR gene is relatively high. Waters et al., (2011) have conducted bovine GHR gene resequensing and found a total of 39 SNP entire gene using five different breeds. One of these SNP is g.257A $>$ G (in exon 10) which causes a change in the amino acid serine to glycine (Ge et al., 2000). This SNP can be identified using PCR-RFLP with AluI restiction enzyme (GHR $\mid$ AluI). The GHR $\mid$ AluI gene was found to be polymorphic in bovine species (Di Stasio et al., 2005; Olenski et al., 2010; Zulkarnaim et al., 2010; Deepika and Salar, 2013; Deng et al., 2015). This polymorphism has been reported to be associated with the final weight and some meat quality traits in some Bos taurus cattle (Di Stasio et al., 2005; Reardon et al., 2010). However, has no association with various body weight parameters including calf birth weight (CBW) in Aberdeen Angus cattle (Fedota et al., 2017), as well as with CBW in Grati-PO cattle (Hartati et al., 2019). However, the associ- 
ation has not been reported yet for other body weight parameters in Grati-PO cattle. Therefore, the present study was aimed to analyze the association between GHR $\mid A l u \mathrm{I}$ gene with body weight parameters in Grati-PO cattle.

\section{MATERIALS AND METHODS}

\section{Performans Data of Grati-PO Cattle}

Grati-PO cattle performance data were collected from 304 animals in the experimental enclosure at the Beef Cattle Research Station including birth, weaning, yearling and 18 months weight were accordance with recording data in breeding activities. Grati-PO cattle blood samples were collected from the jugular vein (3$5 \mathrm{~mL}$ ) using a vaccutainer tube containing $\mathrm{K} 3$ EDTA. DNA was extracted using a Quick-DNA mini prep kit (Zymo Research, USA) and then stored at $-20^{0} \mathrm{C}$ for futher use.

\section{PCR-RFLP Analysis}

The method used to detect DNA variations was PCR-RFLP. The primers used for the $G H R$ gene refers to Di Stasio et al. (2005). The primary sequences of forward and reverse are shown in Table 1. PCR reaction was performed in a total volume of $20 \mu \mathrm{L}$. A total $3 \mu \mathrm{l}$ DNA containing of approximately (10-100) $\mathrm{ng} / \mu \mathrm{L}$ of DNA, $0.2 \mu \mathrm{l}$ of each primer, $10 \mu \mathrm{L}$ PCR mix of MyTaqTM HS Red Mix (Bioline, USA), and 6.2 $\mu 1 \mathrm{ddH}_{2} \mathrm{O}$ to a final volume of $20 \mu \mathrm{l}$. The PCR conditions were pre-denaturation at $95^{\circ} \mathrm{C}$ for 1 min, followed by 35 cycles of denaturation at $95^{\circ} \mathrm{C}$ for $15 \mathrm{~s}$, annealing for $15 \mathrm{~s}$ at $53.8^{\circ} \mathrm{C}$, extension at $72^{\circ} \mathrm{C}$ for $10 \mathrm{~s}$, and a final extension at $72^{\circ} \mathrm{C}$ for $5 \mathrm{~min}$. PCR products were electrophoresed on $1.5 \%$ agarose gels, stained with
GelRed $^{\circledR} 10,000 X$ in water (Biotium, USA) and visualized under a G-BOX Gel Documentation System (Syngene, UK). The PCR products of GHR were digested with $A l u \mathrm{I}$ restriction enzyme (New England Biolabs, USA). The digested fragments were electrophorezed on $2 \%$ agarose gels, stained with GelRed ${ }^{\circledR} 10,000 \mathrm{X}$ in water (Biotium, USA) and visualized under a G-BOX Gel Documentation System (Infiity VX2).

The sequencing analysis was performed in this study using two sample of PCR product (20 $\mu \mathrm{l})$ to confirm the findings. The sequencing analysis was performed through commercial laboratory service (PT Genetika Science).

\section{Statistical Analysis}

Polymorphism indexes such as genotype frequency and allele frequency were calculated according to Nei and Kumar (2000). Expected heterozygosity $(\mathrm{He})$ and observed heterozygosity $(\mathrm{Ho})$ were calculated according to Weir (1991). Polymorphism Information Content (PIC) was calculated according to Botstein et al., (1980) by direct counting. The genotypic frequency distribution for its deviation to HardyWeinberg Equilibrium (HWE) was analyzed by chi-square test was calculated according to Kaps and Lamberson (2004). The number of effective allele was calculated according to formula Nei and Tajima (1981).

Association between GHR $\mid A l u$ I genotype and body weight parameters in Grati-PO cattle population were analyzed applying a randomized block design model as follows :

$$
Y_{i j k}=\mu+\sigma_{i}+\beta_{j}+e_{i j k}
$$

Table 1. GenBank Accession Number, Amplicon Size (bp), Location of Polymorphic Site and Primer Sequence: GHR |AluI Gene of Grati-PO Cattle

\begin{tabular}{ccccc}
\hline Gene & $\begin{array}{c}\text { GenBank } \\
\text { Accession } \\
\text { number }\end{array}$ & $\begin{array}{c}\text { Amplicon } \\
\text { size (bp) }\end{array}$ & $\begin{array}{c}\text { Location of } \\
\text { polymorphic } \\
\text { site }\end{array}$ & Primer Sequences (5'-3') \\
\hline GHR|AluI & AF140284.1 & 342 & Exon 10 & $\begin{array}{l}\text { F:5'-GCT AAC TTC ATC GTG GAC AAC-3' } \\
\text { R : 5'-CTA TGG CAT GAT TTT GTT CAG-3' }\end{array}$ \\
\hline
\end{tabular}

Di Stasio et al. (2005) 


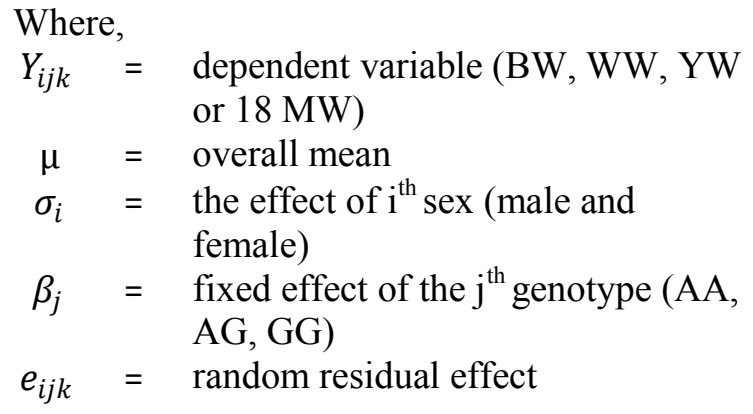

\section{RESULTS AND DISCUSSION}

\section{Body Weight Performance of Grati-PO Cattle}

Descriptive analysis of the body weight performance of Grati-PO cattle in the GHR $\mid$ AluI gene validation material was shown in Table 2 . In this study, the mean of birth weight, weaning weight, yearling weight and 18 months weight of Grati-PO cattle were $25.4 \pm 0.2 \mathrm{~kg} ; 113.8 \pm 2.3$ $\mathrm{kg} ; 159.9 \pm 2.7 \mathrm{~kg}$ and $213.7 \pm 3.6 \mathrm{~kg}$, respectively. The results of statistical analysis show that sex has a significant effect $(\mathrm{P}<0.05)$ on birth weight of Grati-PO cattle. The birth weight male calves was higher than female calves were 26.0 $\pm 0.3 \mathrm{~kg}$ and $24.8 \pm 0.2 \mathrm{~kg}$, respectively. The performance of Grati-PO cattle birth weight in this study was not different from the birth weight in the previous study that was $25.58 \pm 3.31 \mathrm{~kg}$ (Hartati et al., 2015). The birth weight of GratiPO cattle in this study was higher than the birth weight of PO cattle in Napis village, Tambakarejo, Bojonegoro district that was $11.07 \pm 3.92 \mathrm{~kg}$ (Nonok and Darmawan, 2014). However, the birth weight of PO cattle in this study was much lower than those of PO Kebumen which reached $31.88 \pm 3.78 \mathrm{~kg}$ (Maharani et al. 2018) or compared to the same Bos indicus cattle in other country, such as Brahman cattle in Columbia which reach to $33.06 \pm 3.60 \mathrm{~kg}$ (Martínez et al., 2017), and Nellore cattle in Brazil which reach to $32.30 \pm 3.80 \mathrm{~kg}$ (Chud et al., 2014).

In this study showed insignificant results between sex on weaning weight and yearling weight in Grati-PO cattle although during this period, growth was strongly influenced by the environment because at the age of 7 months the calves have begun to wean and learn to consume finished feed until mature. Meanwhile, at 18 months weight there was a very significantly $(\mathrm{P}<0.05)$ between sex, where the body weight of the 18 months PO male cattle : as higher than the female PO cattle $(225.2 \pm 5.8 \mathrm{~kg}$ and 203.2 $\pm 4.2 \mathrm{~kg}$, respectively). This probably because the age of yearling to 18 months was the optimal growth period for beef cattle, male and female cattle growth was influenced by sex steroid hormones. The estrogen hormone can inhibit bone growth, especially at the ends of the bones, so that female growth was stunted after puberty begins, whereas male after puberty will continue to grow for a longer period which was stimulated by androgen hormones (testosterone) especially bone growth and other parts, so that : males were always heavier than females at the same age (Djagra et al., 2002)

\section{GHR|AluI Gene Polymorphism}

Visualization of GHR restriction with $A l u \mathrm{I}$ enzyme, sequence of GHR gene and chromatogram of $G H R$ gene are presented in Figure 1,2 and 3.

In Figure 3 was shown the chromatogram sequence of the GHR gene from individual PO cattle with genotypes AA and GG genotypes. In the GG genotype, there was a substitution of A to $\mathrm{G}$ at exon 10 causing a change in the amino acid serine (AGC) to glycine (GGC). Morihito et al. (2017) stated that the mutation in DNA in organisms was substitutions, deletion or addition of one or more parts of the DNA molecule.

The genotype frequency, allele and heterozygosity of the GHR $\mid A l u$ I gene in Grati-PO cattle were shown in Table 3. The genotype frequency in Grati-PO cattle were detected to have three genotypes, namely AA, AG and GG (Figure 1 and Figure 2). The AA and AG Genotypes of the GHR $\mid A l u$ I gene in Grati-PO cattle were found at almost the same frequency, that were $42.1 \%$ and $44.4 \%$, while the GG genotype was found in the lowest frequency that was $13.5 \%$. The A allele was a common allele found in Grati-PO cattle with a frequency of 0.643 meanwhile the : the G allele was 0.357 . 


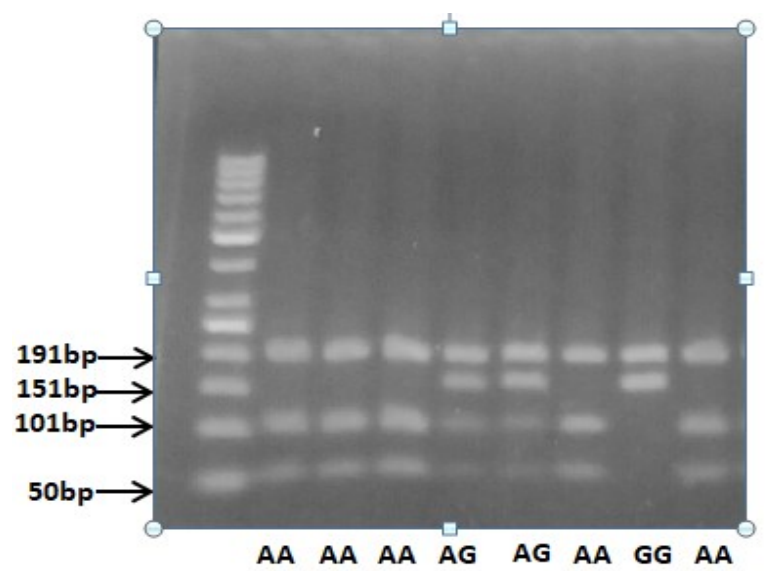

Figure 1. Visualization of $G H R$ restriction with $A l u \mathrm{I}$ restriction enzyme

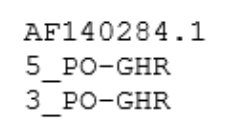

AF140284.1 5_PO-GHR 3_PO-GHR
AF140284.1 5_PO-GHR 3-PO-GHR

GCTAACTTCATCGTGGACAACGCTTACTTCTGCGAGGTAGACGCCAAAAAGTACATTGCC GCTAACTTCATCGTGGACAACGCTTACTTCTGCGAGGTAGACGCCAAAAAGTACATTGCC GCTAACTTCATCGTGGACAACGCTTACTTCTGCGAGGTAGACGCCAAAAAGTACATTGCC

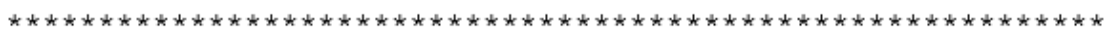
g. $257 \mathrm{~A}>\mathrm{G}$

CTGGCCCCTCATGTCGAGGCTGAATCACACGTAGAGCCAAGCTTTAACCAGGAAGACATT CTGGCCCCTCACGTCGAGGCTGAATCACACGTAGAGCCAGGCTTTAACCAGGAAGACATT CTGGCCCCTCACGTCGAGGCTGAATCACACGTAGAGCCAAGCTTTAACCAGGAAGACATT

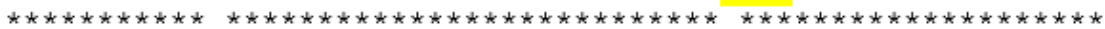

TACATCACCACAGAAAGCCTTACCACTACAGCTGGGAGGTCGGGGACAGCAGAACATGTT TACATCACCACAGAAAGCCTTACCACTACAGCTGGGAGGTCGGGGACAGCAGAACATGTT TACATCACCACAGAAAGCCTTACCACTACAGCTGGGAGGTCGGGGACAGCAGAACATGTT

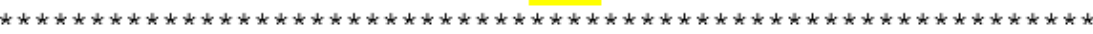

CCAAGTTCTGAGATACCTGTCCCAGATTATACCTTCATTCATATAGTACAGTCTTCACAG CCAAGTTCTGAGATACCTGTCCCAGATTATACCTCCATTCATATAGTACAGTCTCCACAG CCAAGTTCTGAGATACCTGTCCAGATTATACCTCCATTCATATAGTACAGTCTCCACAG

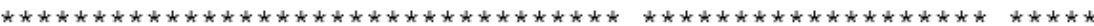

AF140284.1

Figure 2. Sequence alignment of the AA and GG genotype sequenced samples with Genbank AF140284.1 of bovine GHR gene. The g.257A $>\mathrm{G}$ are targeted SNP of bovine GHR gene in present study. The grey highlighted sequences are flanking primers (forward and reverse). The restriction site of AluI (5' $\mathrm{AG}^{\wedge} \mathrm{CT} 3^{\prime}$ ) are shown in the yellow highlighted sequences. The three novel SNPs found between the PO cattle sequences (present study) compared with Genbank (AF140284.1) are indicated by red letters.

The previous research on several local Indonesian beef cattle, the A allele was also a common allele, such as on Grati-Bali Cattle 0.579 (Hartati, et al., 2021), Kebumen cattle
0.58 (Soewandi et al., 2021), Bali cattle 0.991 and Pesisir cattle 0.615 (Zulkharnaim et al., 2010). Likewise with other exotic cattle such as Simmental cattle, the most common genotype 
Table 2. Performance of Grati-PO cattle

\begin{tabular}{lccccc}
\hline Sex & $\mathrm{N}$ & $\mathrm{BW} \pm \mathrm{SE}$ & $\mathrm{WW}+\mathrm{SE}$ & $\mathrm{YW}+\mathrm{SE}$ & $18 \mathrm{MW}+\mathrm{SE}$ \\
\hline Male & 146 & $26,0 \pm 0,3^{\mathrm{a}}$ & $113,2 \pm 3,2$ & $162,1 \pm 4,1$ & $225,2 \pm 5,8^{\mathrm{a}}$ \\
Female & 158 & $24,8 \pm 0,2^{\mathrm{b}}$ & $114,3 \pm 3,2$ & $157,9 \pm 3,5$ & $203,2 \pm 4,2^{\mathrm{b}}$ \\
Total & 304 & $25,4 \pm 0,2$ & $113,8 \pm 2,3$ & $159,9 \pm 2,7$ & $213,7 \pm 3,6$ \\
\hline N : number of observation; BW : birth weight; WW : weaning weight; YW : yearling weight; $18 \mathrm{MW}: 18$ month
\end{tabular}

weight; SE: standard error; means in the same row with different superscripts differ significantly $(\mathrm{P}<0.05)$.

Table 3. Genotype Frequency, Allele and Heterozygosity GHR|AluI Gene of Grati-PO Cattle.

\begin{tabular}{|c|c|c|c|c|c|c|c|c|c|c|c|c|}
\hline \multirow[t]{2}{*}{ Gene } & \multirow{2}{*}{ Sex } & \multirow[t]{2}{*}{$\mathrm{N}$} & \multicolumn{3}{|c|}{ Genotype Frequency } & \multicolumn{2}{|c|}{$\begin{array}{c}\text { Allele } \\
\text { Frequency }\end{array}$} & \multirow[t]{2}{*}{$\chi 2$ test } & \multirow{2}{*}{$\mathrm{He}$} & \multirow[t]{2}{*}{ Ho } & \multirow{2}{*}{ PIC } & \multirow[t]{2}{*}{$\mathrm{Ne}$} \\
\hline & & & $\mathrm{AA}$ & $A G$ & GG & A & G & & & & & \\
\hline \multirow[t]{3}{*}{ GHR } & Male & $\begin{array}{c}14 \\
6\end{array}$ & 0.418 & 0.459 & 0.123 & 0.647 & 0.353 & 0.004 & 0.457 & 0.458 & 0.352 & 1.8 \\
\hline & Female & $\begin{array}{c}15 \\
8\end{array}$ & 0.424 & 0.430 & 0.146 & 0.639 & 0.361 & 0.707 & 0.461 & 0.463 & 0.355 & 1.8 \\
\hline & Total & $\begin{array}{c}30 \\
4 \\
\end{array}$ & 0.421 & 0.444 & 0.135 & 0.643 & 0.357 & 0.323 & 0.459 & 0.460 & 0.354 & 1.849 \\
\hline
\end{tabular}

$\mathrm{N}$ : number of observation; $X^{2}$ test : chi-square value; He : heterozigosity expected; Ho: heterozigosity observed; PIC: polymorphic information content; Ne: number of effective allele.

was the AA genotype (64.19\%) and the A allele was the common alel (0.720) (Ardicli et al., 2017). In contrast, the $G$ allele was the common allele found in Simmental and Limousin cattle raised at Singosari National Artificial Insemination Center BBIB Singosari Malang were 0.714 and 0.735 , respectively (Zulkharnaim et al., 2010).

The results of statistical analysis showed that the genotype frequency of the GHR $\mid A l u$ I gene in Grati-PO cattle was still in HardyWeinberg Equilibrium (HWE). This explains that the frequency of alleles and genotype in the Grati-PO cattle population will remain constant from generation to generation. The PO cattle population was large enough to have the chance to mate randomly, which causes the gene frequency to remain the same. The factors that can change the frequency of genes in a population were selection, mutation, migration, genetic drift and evolution (Falconer and Mackay, 1996).

The genetic diversity of a gene can be evaluated by the heterozygosity value ( $\mathrm{Ho}, \mathrm{He}$, $\mathrm{Ne}$ ) and polymorphism information content (PIC) value. The statistical analysis result showed that the expected heterozygosity (He) and the observed heterozygosity (Ho) values in the GHR $\mid A l u$ I gene were 0.459 and 0.460 . This
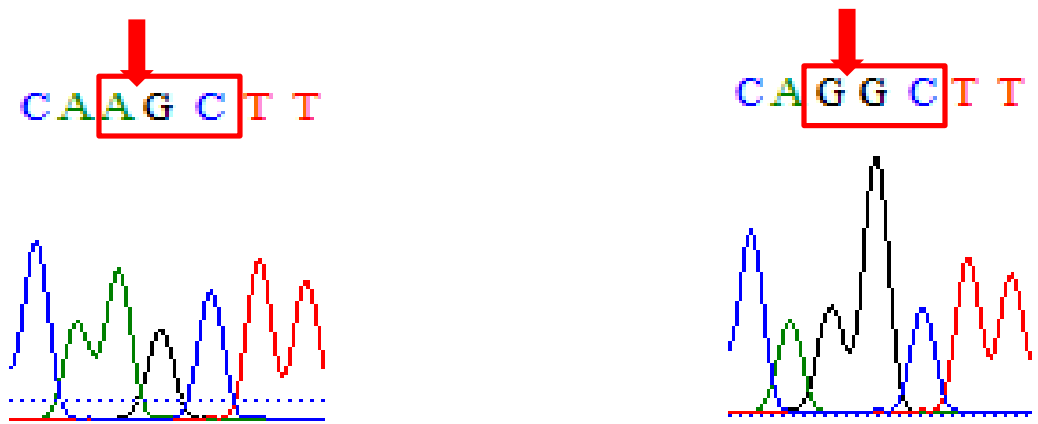

(b)

Figure 3. Chromatogram sequences of GHR gene in individual of (a) PO with AA genotype (b) PO with GG genotype. Substitution of A to $G$ at exon 10 causing a change in the amino acid serine (AGC) to glycine (GGC). 
Table 4. Association between GHR|AluI Gene Polymorphism and Body Weight in Grati-PO Cattle

\begin{tabular}{ccccccccc}
\hline Genotype & $\mathrm{n}$ & $\mathrm{BW} \pm \mathrm{SE}$ & $\mathrm{n}$ & $\mathrm{WW} \pm \mathrm{SE}$ & $\mathrm{n}$ & $\mathrm{WY} \pm \mathrm{SE}$ & $\mathrm{n}$ & $18 \mathrm{MW} \pm \mathrm{SE}$ \\
\hline Male (M) & & & & & & & & \\
AA & 61 & $25.8 \pm 0.4$ & 60 & $108.0 \pm 4.5$ & 60 & $147.6 \pm 5.2$ & 58 & $202.1 \pm 7.1$ \\
AG & 67 & $26.1 \pm 0.4$ & 67 & $117.8 \pm 5.2$ & 67 & $174.4 \pm 6.5$ & 66 & $242.6 \pm 9.1$ \\
GG & 18 & $26.4 \pm 1.0$ & 17 & $113.4 \pm 7.5$ & 17 & $164.9 \pm 11.8$ & 17 & $236.3 \pm 17.7$ \\
Female (F) & & & & & & & & \\
AA & 67 & $25.3 \pm 0.4$ & 67 & $104.4 \pm 3.5$ & 67 & $146.9 \pm 4.9$ & 67 & $179.8 \pm 4.0$ \\
AG & 68 & $24.6 \pm 0.3$ & 64 & $122.4 \pm 5.7$ & 64 & $170.3 \pm 5.3$ & 64 & $224.9 \pm 7.3$ \\
GG & 23 & $23.9 \pm 0.7$ & 23 & $120.6 \pm 9.9$ & 23 & $155.4 \pm 9.8$ & 23 & $211.0 \pm 11.6$ \\
M and F & & & & & & & & \\
AA & 128 & $25.5 \pm 0.3$ & 127 & $106.1 \pm 2.8^{\mathrm{a}}$ & 127 & $147.2 \pm 3.5^{\mathrm{a}}$ & 125 & $190.2 \pm 4.1^{\mathrm{a}}$ \\
AG & 135 & $25.3 \pm 0.3$ & 131 & $120.0 \pm 3.8^{\mathrm{b}}$ & 131 & $172.4 \pm 4.2^{\mathrm{b}}$ & 130 & $233.9 \pm 5.9^{\mathrm{b}}$ \\
GG & 41 & $25.0 \pm 0.6$ & 40 & $117.5 \pm 6.5^{\mathrm{ab}}$ & 40 & $159.4 \pm 7.5^{\mathrm{ab}}$ & 40 & $221.8 \pm 10.1^{\mathrm{b}}$ \\
\hline
\end{tabular}

$\mathrm{n}=$ number of observation; BW : birth weight; WW : weaning weight; YW : yearling weight; $18 \mathrm{MW}$ : 18 month weight; SE: standard error; means in the same row with different superscripts differ significantly $(\mathrm{P}<0.05)$.

result shows that Grati-PO cattle have a high enough value on genetic diversity. The Ne valu in this study was 1.849 which means that there were differences in allele frequencies in the GHR $\mid$ AluI gene for Grati-PO cattle. Determination of the informative level of a marker can be seen from the PIC value with with three categories, namely the low category $(\leq 0.25)$, the moderate category $(0.25<\mathrm{PIC}<0.5)$, and high category $(\geq 0.5)$. The PIC value was 0.354 and in the moderate category. The PIC value of Grati-PO cattle in this study was included in the moderate category which indicated that the markers on the GHR $\mid A l u$ I gene were very informative so that it can be associated with body weight in the GratiPO cattle population.

\section{Association of GHR | AluI Gene with Body Weight in Grati-PO Cattle}

The analysis result of the association of GHR $\mid A l u$ I genotypes with body weight of GratiPO cattle are presented in Table 4 . The statistical analysis results showed that there was no interaction between sex and genotype even though the effect of sex was significantly different on birth weight and body weight at 18 months (Table 2). The genotype of the GHR $\mid$ AluI gene was significantly $(\mathrm{P}<0.05)$ associated to weaning weight, yearling weight and 18 months weight in Grati-
PO cattle but not significant $(\mathrm{P}>0.05)$ with birth weight of Grati-PO cattle. The GHR gene was also reported to be significantly associated with weaning weight and daily weight gain in Pasundan cattle (Said et al., 2016), weight gain and carcass weight in Nellore cattle (Bos indicus) and it cross breed (Curi et al., 2006) but it has no effect on reproductive performance in HolsteinFriesian cattle (Hadi et al., 2015). In Bos taurus cattle, the GHR $\mid$ AluI was found to be associated with birth weight, final wieght and several characteristics of meat quality (Di Stasio et al., 2005; Reardon et al., 2010).

This research found that the AG genotype in Grati-PO cattle has the highest body weight performance both at weaning weight, yearling weight and 18 months weight. Based on the results of this study, genotype-based selection can be carried out on individuals with the AG genotype with the selection criteria for weaning weight or yearling weight. Weaning weight and yearling weight were two growth characteristics that has high economic value. The high weaning weight illustrates the mother's good mothering ability in raising calves and having good milk production (Falconer and Mackay 1996). In addition, the heritability value obtained for the two traits where the highest heritability was obtained at the weaning and yearling weight of $0.47 \pm 0.15$ 
and $0.63 \pm 0.17$, respectively (Hartati et al., 2015). Thus it could be proposed that the GHR gene is very potential and could be used as a genetic marker on genetic improvement and selection for superior of Grati-PO cattle .

\section{CONCLUSION}

The GHR $\mid A l u$ I gene was found to be moderately polymorphic in Grati-PO cattle. There was no association between GHR $\mid A l u$ I gene genotype and birth weight, but it was significant with weaning weight, yearling weight and 18 month weight. Therefore, GHR $\mid A l u$ I gene may be a potential genetic marker for those three body weight parameters in Grati-PO cattle. However, this association needs to be validated to the subsequent offspring so that it can optimistically be used as a genetic marker in improving body weight performance in the breeding program for Grati-PO cattle.

\section{ACKNOWLEDGEMENTS}

This study was founded by The Indonesian Agency for Agricultural Research and Development (IAARD) through Kegiatan Kerjasama Penelitian, Pengkajian dan Pengembangan Pertanian Strategis (KP4S) on contract number 31.14/PL.040/H.1/02/2018.K. The author would like to thank all the Indonesia Beef Cattle Research Station of Grati Pasuruan teams who helped carry out this research.

\section{REFERENCES}

Albertí, P., B. Panea, C. Sañudo, J.L. Olleta, G. Ripoll, P. Ertbjerg, M. Christensen, S. Gigli, S. Failla, S. Concetti, J.F. Hocquette, R. Jailler, S. Rudel, G. Renand, G.R. Nute, R.I. Richardson and J.L. Williams. 2008. Live weight, body size and carcass characteristics of young bulls of fifteen European breeds. Livest. Sci. 114: 19-30

Ardicli, S., D. Dincel., H. Samli and F. Balci. 2017. Effects of Polymorphisms at LEP, CAST, CAPN1, GHR, FABP4 and
DGAT1 genes on fattening performance and carcass traits in Simmental bulls. Arch. Anim. Breed. 60: 61-70.

Botstein, D., R.L. White, M. Skolnick and R.W. Davis. 1980. Construction of a genetic linkage map in man using restriction fragment length polymorphisms. Am. J. Hum. Genet. 32:314-31

Soewandi, B. D. P., Hartati and A. A. R. Hapsari. 2021. Identification of growth hormone gene polymorphism and its association with body weight in PO Kebumen cattle. 2021. The 7th International Conference on Sustainable Agriculture and Environment IOP Conf. Series: Earth and Environmental Science $637 \quad$ (2021) 012072 .

Buzanskas, M. E., D. A. Grossi, R. V. Ventura, F. S. Schenkel, M. Sargolzaei, S. L. C. Meirelles, F. B. Mokry, R. H. Higa, M. A. Mudadu, M. V. G. B. da Silva, S. C. M. Niciura, R. A. A. T. Junior, M. M. Alencar, L. C. A. Regitano and D. P. Munari. 2014. Genome-wide association for growth traits in Canchim beef cattle. PLoS ONE 9(4): e94802. doi:10.1371/ journal.pone.0094802

Cady, G., T. Landeryou, M. Garratt, J. J. Kopchick, N. Qi, D. Garcia-Galiano, C. F. Elias, M. G. Myers., R. A. Miller, D.A. Sandoval and M. Sadagurski.

2017. Hypothalamic growth hormone receptor (GHR) controls hepaticglucose production in nutrient-sensing leptin receptor (LepRb) expressing neurons. Mol. Metab. 6:393-405

Chia, D.J. 2014. Minireview: Mechanisms of growth hormone mediated gene regulation. Mol. Endocrinol. 28: 1012-1025

Chud, T.C.S., S.L. Caetano, M.E. Buzanskas, D.A. Grossi, D.G.F. Guidolin, G.B. Nascimento, J.O. Rosa, R.B. Lobo and D.P. Munari. 2014. Genetic analysis for gestation length,birth weight, weaning weight, and accumulated productivity in Nellore beef cattle. Livest. Sci.170:16-21

Coyne, J.M., Ross D. Evans and D.P. Berry. 
2019. Dressing percentage and the differential between live weight and carcass weight in cattle are influenced by both genetic and non-genetic factors. J. Anim. Sci. 2019.97:1501-1512

Curi, R.A., H.N. Oliveira, A.C. Silveira and C.R. Lopes. 2006. Effects of polymorphic microsatellites in the regulatory region of IGF1 and GHR on growth and carcass traits in beef cattle. Anim. Genet. 36:5862

Deepika, R., and K. Salar. 2013. Polymorphism studies of growth hormone receptor (GHR) gene in Indigenous Grey cattle breeds of India. DHR-IJBLS. 4:270-277

Deng, F., C. Xia, X. Jia, T. Song, J. Liu, S. Lai and S. Chen .2015. Comparative study on the genetic diversity of ghr gene in tibetan cattle and holstein cows. Anim. Biotechnol. 26: 217-221

Di Stasio, L., G. Destefanis, A. Brugiapaglia, A. Albera and A. Rolando. 2005. Polymorphism of the GHR gene in cattle and relationships with meat production and quality. Anim. Genet.36:138-140

Djagra, I.B., I.G.N.R. Haryana, I.G.M. Putra, I.B. Mantra, A.A. Oka. 2002. Standard Body Size of Bali Cattle. Report of Research Results. Cooperation between Bappeda of Bali Province and the Faculty of Animal Husbandry, Udayana University, Denpasar.

Falconer, D.S. and T.F.C. Mackay. 1996. Introduction to Quantitative Genetic. 4th ed. Prince John. North Canada State University Press, Kanada.

Fedota, O.M., N.G. Lysenkoa, S. Yu. Rubanb, O.I. Kolisnykc and I.V. Goraychukd. 2017. The effects of polymorphisms in growth hormone and growth hormone receptor genes on production and reproduction traits in Aberdeen-Angus cattle (Bos taurus L., 1758). Cytol. Genet. 51: 352 360

Ge,W., M.E. Davis, H.C. Hines and K.M. Irvin. 2000. Rapid Communication: Single nucleotide polymorphisms detected in exon 10 of the bovine growth hormone receptor gene. J. Anim. Sci.78:2229-2230

Ge, W., M. E. Davis, H.C. Hines, K.M. Irvin and R.C.M. Simmen. 2003. Association of single nucleotide polymorphisms in the growth hormone and growth hormone receptor genes with blood serum insulin-like growth factor I concentration and growth traits in Angus cattle. J. Anim. Sci. 81:641-648

Hadi, Z., H. Atashi, M. Dadpasand, A. Derakhshandeh and S.M.M. Ghahramani. 2015. The relationship between growth hormone polymorphism and growth hormone receptor genes with milk yield and reproductive performance in Holstein dairy cows. IJVR.15: 244-248

Hartati, Muladno, Jakaria, R. Priyanto, A. Gunawan, Aryogi and C. Thalib. 2015. Heritability estimation and non genetic factors affecting production traits of Indonesian Ongole Cross.Indones. JITV. 20:168-174

Hartati, H., B.D.P. Soewandi, A.A.R. Hapsari, S. Anwar and D. Pamungkas. 2019. Identification of GH|MspI and GHR|AluI gene polymorphism and its association with calf birth weight of Grati-PO Cattle.Indones. JITV. 24 49-55

Hartati, M. Luthfi, D. Ratnawati and B.D.P Soewandi. 2021. Detection of growth hormone (GH|MspI,GHR|AluI, Pit1|HinfI) genes polymorphism and its association with body weight of Grati-Bali Cattle (Bos sondaicus). IOP Conf. Series: Earth and Environmental Science $788 \quad$ (2021) 012010. The 3rd International Conference of Animal Science and Technology. doi:10.1088/1755-1315/788/1/012010

Kaps M. and W. R. Lamberson. 2004. Biostatistics for Animal Science. CABI Publishing, London.

Maharani, D., A. Fathoni, Sumadi, T. Hartatik and M.Khusnudin. 2018. Identification of MC4R gene and its association with body weight and body size in Kebumen Ongole Grade cattle. J. Indonesian Trop. Anim. Agric. 43:87-93

Martínez, R. D. Bejarano, Y. Gómez, R. Dason- 
eville, A. Jiménez, G. Even, J. Sölkner, and G. Mészáros. 2017. Genome-wide association study for birth, weaning and yearling weight in Colombian Brahman cattle. Genet. Mol. Biol. 40:453-459.

Meyer K. 1995. Estimates of genetic parameters for mature weight of Australian beef cows and its relationship to early growth and skeletal measures. Livest. Prod. Sci. 44:125-137

Moody D.E., D. Pomp, W. Barendse and J.E. Womack. 1995. Assignment of the growth hormone receptor gene to bovine chromosome 20 using linkage analysis and somatic cell mapping. Anim. Genet. 26:341-343

Morihito, Rondo V.S.A, Stephanie E Chungdinata, Timboeleng A Nazareth, M Iqbal Pulukadang, Roy A.M Makalew, and Benny Pinontoan. 2017. "Identifikasi Perubahan Struktur DNA Terhadap Pembentukan Sel Kanker Menggunakan Dekomposisi Graf." Jurnal Ilmiah Sains 17 (2): 153. doi:10.35799/jis.17.2.2017.17368.

Nei, M., and F. Tajima. 1981. Genetic drift and estimation of effective population size. Genetics. 98:625-640

Nei, M. and S. Kumar. 2000. Molecular Evolution and Phylogenetics. Oxford University Press, New York.

Nonok, S., and H. Darmawan. 2014. Genetic profile and Ongole breed cattle breeders as a basic strategy for the development of the village for animal breeding centers. Buana Sains. 14: 71-84

Oleński, K., T. Suchocki and S. Kamiński. 2010. Inconsistency of associations between growth hormone receptor gene polymor- phism and milk performance traits in Polish Holstein-Friesian cows and bulls. Anim. Sci. Pap. Reports. 28: 229-234

Putra, W. P. B., Sumadi and T. Hartatik. 2014. The genetic correlation of growth traits in Aceh cattle at indrapuri district Aceh Province. J. Agripet. 14:37-41

Reardon W, A.M. Mullen, T. Sweeney and R.M. Hamill. 2010. Association of polymorphisms in candidate genes with colour, water-holding capacity, and composition traits in bovine $\mathrm{M}$. longissimus and $\mathrm{M}$. semimembranosus. Meat Sci. 86: 270-275

Said, S., P.P. Agung, W.P.B. Putra, S. Anwar and A.S. Wulandari. 2016. Estimation of most probable producing ability value for calf birth's performance in Sumba Ongole cows. J. Indonesian Trop. Anim. Agric. 41: $53-60$

Waters, M.J., and A.J. Brooks. 2015. JAK2 activation by growth hormone and other cytokines. Biochem. J. 466:1-11

Waters, S. M. , M. S. McCabe, D. J. Howard, L. Giblin, D. A. Magee, D. E. MacHugh and D. P. Berry. 2011. Associations between newly discovered polymorphisms in the Bos taurus growth hormone receptor gene and performance traits in Holstein -Friesian dairy cattle. Anim. Genet. 42:3949

Weir, B.S. 1991. Genetic Data Analysis II: Methods for Discrete Population Genetic Data. Inc. Publishers, Sunderland.

Zulkharnaim, Jakaria and R.R. Noor. 2010. Identification of genetic diversity of growth hormone receptor (GHR|AluI) gene in Bali cattle. Media Peternakan, 33:81-87 